\title{
Optimization of Cyclodextrin Glycosyltransferase Production from Sorghum
}

Bernardi NZ1 ${ }^{1}$ Blanco $\mathrm{KC}^{2}$, Monti $\mathbf{R}^{3}$ and Contiero $\mathrm{J}^{1 *}$

${ }^{1}$ Unesp-Universidade Estadual Paulista, Biological Sciences Institute, Department of Biochemistry and Microbiology, Laboratory of Industrial Microbiology, 24A Avenue, Bela Vista, IBRC, RioClaroSP, CEP13506-900, Brazil

${ }^{2}$ University of São Paulo, São Carlos Institute of Physics, São Carlos, São Paulo, Brazil

${ }^{3}$ Unesp-Faculty of Pharmaceutical Sciences, Departament of Food and Nutrition, Araraquara, Rodovia Araraquara - Jaú, Km 1, Araraquara, SP, Brazil

\begin{abstract}
A central composite experimental design was used to evaluate optimal conditions of the medium component, $\mathrm{pH}$ and temperature for cyclodextrin glycosyltransferase production from sorghum by Bacillus circulans (American Type Culture Collection). Sorghum concentration, initial $\mathrm{pH}$ and temperature were optimized using the response surface method. Maximal CGTase production of $216.94 \mathrm{U} \cdot \mathrm{mL}^{-1}$ was obtained after 48 hours of fermentation when the concentrations of the medium were $0.16 \%$ sifted sorghum, $0.5 \%$ triptone, $0.5 \%$ yeast extract, $1 \%$ sodium carbonate, $0.1 \% \mathrm{~K}_{2} \mathrm{HPO}_{4}, 0.02 \% \mathrm{MgSO}_{4} \cdot 7 \mathrm{H}_{2} \mathrm{O}$, initial pH of 8.0 and temperature of $35^{\circ} \mathrm{C}$ under rotational shaking. Further studies aimed at increasing the fermentation scale using optimal conditions for the high enzymatic production and high volumetric productivity are needed to improve the fermentation process described in the present study.
\end{abstract}

Keywords: Sorghum; Response surface methodology; Optimization of production; Cyclodextrin glycosyltransferase

\section{Introduction}

Cyclodextrins (CDs) are cyclic oligosaccharides with a variable number of glucose units joined by a linkages -1.4 , the most common features of which are 6,7 and 8 glucose units with diameters of about $5.2 \AA(\alpha-C D), 6.6 \AA(\beta-C D)$ and $8.4 \AA(\gamma-C D)[1]$ and sufficiently hydrophilic externally to make CDs water soluble [2]. CDs solubilize and modify drugs, foods, cosmetics, etc. due to the formation of inclusion complexes [3]. Cyclodextrin glycosyltransferase (CGTase) EC 2.4.1.19 ( $\alpha$-1,4-glucan 4-glycosyltransferase) is a monomeric enzyme with a molecular weight of around $75 \mathrm{kDa}$ [4]. CGTase has an amino acid sequence similar to that of the enzyme $\alpha$-amylase and therefore belongs to the amylase family. This enzyme catalyzes the conversion of starch into CDs through a reversible intramolecular transglycosylation reaction, cyclization, hydrolysis and coupling to the starch [5].

CDs production involves starch treatment with CGTase produced by bacteria [6]. The selection of carbon sources is a critical factor in the fermentation process for CGTase production. The wrong carbon source may cause catabolite repression of the enzyme production and reduce the growth rate of the microorganism [7]. Sorghum is a starchrich grain grown widely in Brazil. The increase in sorghum crops is due the capacity of the plant to adapt to conditions of water deficiency and recycle nutrients in the soil. Nitrogen fixation in sorghum crops has been addressed in recent studies [8]. According to the National Sorghum Producers, sorghum has a low production cost - at least 20 percent less than other major grain crops. Thus, the use of sorghum as a source for downstream products has an economic benefit. The sorghum has been used as a carbon source for products as ethanol [9] and Lactic acid except for CGTase production are not yet known [10].

Sorghum use as a carbon source in the media may lower the cost of CGTase production. The aims of the present study were to evaluate the use of sorghum as a substrate for the production of CGTase using the microorganism Bacillus circulans and optimize its concentration and other production variables, such as temperature and initial $\mathrm{pH}$, in an experimental design.

\section{Materials and Methods}

\section{Analysis of starch in Sorghum}

The starch in sorghum was calculated as the difference between total sugars and reducing sugars: Sorghum starch = total sugars reducing sugars.

For the analysis of total sugars, $2 \mathrm{~g}$ of sorghum were transferred to a $100-\mathrm{mL}$ Erlenmeyer flask; $1 \mathrm{ml}$ of sodium hydroxide $10 \%(\mathrm{v} / \mathrm{v})$ was added and autoclaved $\left(1 \mathrm{~atm}\right.$ at $120^{\circ} \mathrm{C}$ ) for 1 hour. At room temperature, $10 \mathrm{ml}$ of hydrochloric acid were added and autoclaved again (1 atm at $120^{\circ} \mathrm{C}$ ) for 30 . At $25^{\circ} \mathrm{C}$, the excess hydrochloride acid was neutralized with sodium hydroxide $40 \%(\mathrm{v} / \mathrm{v})$, transferred to a $500-\mathrm{mL}$ volumetric flask and the volume was completed with distilled water. The resultant solution was stirred and filtered with dry filter paper $(90 \mathrm{~mm})$. Two hundred fifty $\mu \mathrm{L}$ of filtered solution were added to $250 \mu \mathrm{L}$ of 3,5-dinitro salicyclic acid (DNS), boiled for $5 \mathrm{~min}$. and cooled. Absorbance of the final solution was read using a spectrophotometer at $540 \mathrm{~nm}$. The standard curve was made with glucose P.A.

For the analysis of reducing sugars, $2 \mathrm{~g}$ of sorghum was transferred to a 500-mL volumetric flask; the volume was completed with distilled water, stirred and filtered with dry filter paper $(90 \mathrm{~mm})$. Two hundred fifty $\mu \mathrm{L}$ of the solution volume were added to $250 \mu \mathrm{L}$ of DNS, boiled for $5 \mathrm{~min}$. and cooled in an ice bath. Absorbance of the final solution was read using a spectrophotometer at $540 \mathrm{~nm}$. The standard curve was made with glucose P.A.

*Corresonding author: Natalia Sozza Bernardi Bernardi, SN Best regards Prof. Dr. Jonas Contiero Lab. de Microbiologia Industrial Depto de Bioquímica e Microbiologia UNESP - Universidade Estadual Paulista "Julio de Mesquita Filho" Av. 24A, no 1515 Bela Vista, Rio Claro - SP, 3506-900, Tel: +55 19 35264101; Fax: +55 19 35264176; E-mail: jconti@rc.unesp.br.

Received October 06, 2015; Accepted October 27, 2015; Published November 02, 2015

Citation: Bernardi NZ, Blanco KC, Monti R, Contiero J (2015) Optimization of Cyclodextrin Glycosyltransferase Production from Sorghum. J Food Ind Microbiol 1: 102. doi:10.4172/2572-4134.1000102

Copyright: (c) 2015 Bernardi NZ, et al. This is an open-access article distributed under the terms of the Creative Commons Attribution License, which permits unrestricted use, distribution, and reproduction in any medium, provided the original author and source are credited. 


\section{Microorganism}

Bacillus circulans was acquired from the culture collection of the Industrial Microbiology Laboratory of the Biological Sciences Institute of Rio Claro (SP, Brazil) and was originally purchased from the American Type Culture Collection.

Activation of inoculum: Bacillus circulans was cultured in a medium $(100 \mathrm{~mL})$ containing $(\mathrm{w} / \mathrm{v}) 1 \%$ soluble starch, $0.5 \%$ yeast extract, $0.5 \%$ tryptone, $0.1 \% \mathrm{~K}_{2} \mathrm{HPO}_{4}$ and $0.02 \% \mathrm{MgSO}_{4} \cdot 7 \mathrm{H}_{2} \mathrm{O}$, completed with $10 \% \mathrm{Na}_{2} \mathrm{CO}_{3}$ in a $300-\mathrm{mL}$ Erlenmeyer flask at 150 $\mathrm{rpm}$ and $35^{\circ} \mathrm{C}$. Successive transferences were performed at eight-hour intervals for $72 \mathrm{~h}$. The centrifuged broth of the last peal was centrifuged and stored with $40 \%$ glycerol at $-80^{\circ} \mathrm{C}$.

\section{Enzyme production}

The parameters affecting CGTase production, such as the carbon source (sorghum), Nakamura and Horikoshi (1976) medium, temperature and initial $\mathrm{pH}$, were studied using a central composite design [11]. Bacillus circulans was cultured in 300-mL Erlenmeyer flasks containing $100 \mathrm{~mL}$ of modified Nakamura and Horikoshi (1976) medium incubated at $150 \mathrm{rpm}$ for 24,48 and $72 \mathrm{~h}$. The production broth was centrifuged at $10,000 \mathrm{rpm}$ for $10 \mathrm{~min}$. and the cell-free of supernatant was used for the determination and enzyme activity.

Enzyme activity (EA) was measured using the phenolphthalein method [12]. Five $\mathrm{mL}$ of the supernatant from the enzyme broth and $5.0 \mathrm{~mL}$ of $1 \%$ starch solution [0.1 $\mathrm{g}$ of soluble starch, $1.0 \mathrm{~mL}$ of $\mathrm{CaCl}_{2}$ solution $(0.05 \mathrm{M}), 1.0 \mathrm{~mL}$ of Tris- $\mathrm{HCl}$ buffer solution $(0.05 \mathrm{M} ; \mathrm{pH}$ 8.0 ) and distilled water for a final volume of $10 \mathrm{~mL}$ ] were placed in a thermostatic reactor at $55 \pm 1{ }^{\circ} \mathrm{C}$. Samples were withdrawn at zero, three, six, nine and $12 \mathrm{~min}$. and inactivated at $100^{\circ} \mathrm{C}$ for five min. Cyclodextrin was quantified as a function of time by adding $2.5 \mathrm{~mL}$ of phenolphthalein solution ( $\mathrm{pH} 10.5$ ) to $0.5 \mathrm{~mL}$ of the inactivated samples. Absorbance of the final solution was read in a spectrophotometer at $550 \mathrm{~nm}$. EA was defined as the amount of cyclodextrin produced per min. and determined by Equation 1.

$$
\mathrm{A}=\alpha . \beta . F d i l .1000 \text {.(Vrector/Venzymatic) }
$$

in which $\mathrm{A}$ is enzyme activity $(\mu \mathrm{mol} / \mathrm{min} . / \mathrm{mL}) ; \alpha$ is the slope of the standard curve ( $\left.\mu \mathrm{mol} . \mathrm{mL}^{-1} / \mathrm{ABS}\right) ; \beta$ is the slope of the experimental curve $(\mathrm{ABS} / \mathrm{min}$.); $\mathrm{V}$ is the enzyme volume of the sample; and Fdil is the dilution factor.

\section{Statistical analysis}

The Statistic 7.0 program (Stat Soft, Tulsa, OK, USA) was used for the experimental design and multiple regression analysis of the data. The response surface methodology was employed to determine the interaction between process variables, optimize the results and minimize the variability in the results. Multiple regression analysis was performed and the equation representing the model was statistically analyzed with the coefficient of determination (R). The F-test and t-test established the statistical significance of the proposed model.

\section{Carbon source selection}

The selection of the carbon source was performed by substituting the carbon source in the Nakamura and Horikoshi culture medium with sour and sweet cassava (starches that differ in acidity), sorghum and a commercial soluble starch [11].

\section{Central composite design}

Experiments were performed to determine the influence of the variables on the enzyme production process using two experimental central composite designs. The variables of the first and second planning performed in shake flasks were $\mathrm{X}_{1} \equiv$ sorghum starch (\%), $\mathrm{X}_{2} \equiv$ initial $\mathrm{pH}$ and $\mathrm{X}_{3} \equiv$ temperature. The levels of the variables studied were placed in coded form in Table 1, using the following encoding equation for each experimental design:

\section{$\mathrm{xi}=(\mathrm{Xi}-\mathrm{Xcp}) / \Delta \mathrm{Xi}$}

in which $\mathrm{xi}$ is the coded value of the independent variable; $\mathrm{Xi}$ is the real value of the independent variable; $X c p$ is the real value of an independent variable at the central point; and $\Delta \mathrm{Xi}$ is the step change value. Table 1 displays the variations and levels of the independent variables analyzed. The root mean square was generated from an empirical equation produced by the central composite design.

\section{Results and Discussion}

The choice of sorghum grain was determined after preliminary testing with different carbon sources in the Nakamura and Horikoshi culture medium: sour and sweet cassava, sorghum in nature and soluble starch. Sorghum starch proved to be the best carbon source for CGTase production. This is due the fact that the sorghum grain (ranging in size from 6 to $30 \mu \mathrm{m}$ ) exhibits $100 \%$ amylopectin [13] and CGTase breaks the $\alpha-1,4$ starch bonds in order to catalyze the transference of amylopectin into CDs [14]. A number of different several carbon sources have been employed to reduce CGTase production costs. Cassava starch is cheaper than commercial potato starch and has been used to optimize the production of CGTase from Bacillus lehensis [15]. Kulpreecha et. al. (2009) used corn and rice as carbon sources to produce CGTase [16].

Table 2 displays the test results for the total and reducing sugars and starch concentration with different sorghum grain sizes (based on mesh scale): non-sifted sorghum seed and 1.19, 0.71, 0.5 and 0.064 meshes. Total and reducing sugars, starch and enzyme activity were tested at 24 -hour intervals for 72 hours.

Table 2 also displays the relationship between sorghum grain size, percentage of starch and enzyme activity, using each different grain size as substrate. The same amount of grain has different starch concentrations depending on seed size. Starch and glucose concentrations were greatest in the non-sifted grain. A direct correlation was found between grain size and enzyme activity. The

\begin{tabular}{|l|l|l|l|l|l|}
\hline Variables & \multicolumn{9}{l}{ Range and levels } \\
\cline { 2 - 6 } & $-\alpha$ & -1 & 0 & 1 & $+\alpha$ \\
\hline Sorghum $\left(\mathrm{X}_{1}\right)$ & 0.33 & 1 & 0.8 & 1 & 1.17 \\
\hline $\mathrm{pH}\left(\mathrm{X}_{2}\right)$ & 6.32 & 7 & 8 & 9 & 9.98 \\
\hline Temperature $\left(\mathrm{X}_{3}\right)$ & 33.3 & 34 & 35 & 36 & 36.7 \\
\hline
\end{tabular}

Table 1: Experimental range and levels of independent variables used in central composite design.

\begin{tabular}{|c|c|c|c|c|c|}
\hline $\begin{array}{c}\text { Sample } \\
\text { (mesh) }\end{array}$ & Total sugar & Reducing sugar & \multicolumn{3}{|c|}{ Starch } \\
\cline { 2 - 6 } & $\mathbf{( g \cdot \mathbf { L } ^ { - 1 } )}$ & $\mathbf{( g \cdot \mathbf { L } ^ { - 1 } )}$ & $\begin{array}{c}\text { Non-reducing } \\
\text { sugar }\left(\mathbf{g} \cdot \mathbf{L}^{-1} \mathbf{)}\right.\end{array}$ & Starch (\%) & $\begin{array}{c}\text { EA } \\
\left(\mathbf{U} \cdot \mathbf{m L}^{-1} \mathbf{)}\right.\end{array}$ \\
\hline 0.06 & 1.19 & 0.21 & 0.98 & 24.40 & 190.99 \\
\hline 0.5 & 1.27 & 0.31 & 0.96 & 24.00 & 191.68 \\
\hline 0.71 & 1.34 & 0.37 & 0.97 & 24.20 & 172.65 \\
\hline 1.19 & 1.45 & 0.4 & 1.05 & 25.40 & 186.84 \\
\hline SG $^{*}$ & 1.51 & 0.48 & 1.03 & 26.80 & 227.49 \\
\hline
\end{tabular}

*Non-sifted sorghum grain

Table 2: Total and reducing sugars, starch concentration and enzyme activity with different sizes of sorghum grain. 
highest concentration of starch from sorghum corresponds to the greatest enzyme activity. This is due to capacity of Bacillus circulans to use the non-sifted grain easily, possibility due to size of the starch molecule and/or its position on the grain.

Culture conditions regarding sorghum concentration, $\mathrm{pH}$ and temperature for CGTase production were optimized using the response surface methodology. Table 3 displays the design matrix in coded and real variables and respective results (enzyme activity).

The greatest CGTase production was $216.94 \mathrm{U} \cdot \mathrm{mL}^{-1}$, obtained with $0.162 \%$ sorghum and $\mathrm{pH} 8$ at $35^{\circ} \mathrm{C}$ (Table 3, experiment 15). Multiple regression analysis was performed on the data. Equation 3 describes the experimental data.

$\mathrm{EA}=205.26-11.15 \mathrm{X}_{1}+3.44 \mathrm{X}_{2}+24.82 \mathrm{X}_{3}+7.81 \mathrm{X}_{1} \mathrm{X}_{2}+15.74 \mathrm{X}_{1} \mathrm{X}_{3}-$ $23.24 \mathrm{X}_{2} \mathrm{X}_{3}-1.59 \mathrm{X}_{1}^{2}-11.64 \mathrm{X}_{2}^{2}-42.55 \mathrm{X}_{3}^{2}$

The quadratic model relates three linear terms, three quadratic terms and three factorial interactions, in which $\mathrm{Y}$ is the predicted response (EA) and $\mathrm{X}_{1}, \mathrm{X}_{2}$ and $\mathrm{X}_{3}$ are the coded values of sorghum, initial $\mathrm{pH}$ and temperature, respectively.

Table 4 displays the Student's t-distribution and $\mathrm{p}$-values that describe the significant probability (less than $\alpha=0.1$ ). The results demonstrate the significant effect of the variables $\mathrm{X}_{1}$ (sorghum), $\mathrm{X}_{2}$ (initial $\mathrm{pH}$ ) and $\mathrm{X}_{3}$ (temperature). The isolated variables $\mathrm{X}_{2}$ and $\mathrm{X}_{3}$ and quadratic variables $\mathrm{X}_{1}^{2}, \mathrm{X}_{2}^{2}$ and $\mathrm{X}_{3}^{2}$ have positive coefficients, meaning that an increase in their values results in an increase in enzyme yield. The isolated variable $\mathrm{X}_{1}$ and the $\mathrm{X}_{2} \mathrm{X}_{3}$ interaction have negative coefficients, meaning that an increase in their values results in a reduction in enzyme production.

The non-significant terms $\mathrm{X}_{1} \mathrm{X}_{2}$ and $\mathrm{X}_{1} \mathrm{X}_{3}$ were discarded and the reduced Equation 4 was generated to represent the CGTase production model.
$\mathrm{EA}=209.19+5.83 \mathrm{X}_{1}-8.62 \mathrm{X}_{2}-24.07 \mathrm{X}_{3}+8.60 \mathrm{X}_{2} \mathrm{X}_{3}-27.22 \mathrm{X}_{1}^{2}-52.00 \mathrm{X}_{2}^{2}-$ $20.37 \mathrm{X}_{3}^{2}$

ANOVA of the quadratic regression model demonstrated in Eq. 4 was highly significant, which is evident from the results of Fisher's F-test, which had a very low probability value $[(\mathrm{p}$ model $>\mathrm{F})=0.0000]$. The adjusted model was checked by the coefficient of determination $\left(\mathrm{R}^{2}\right)$ and the multiple correlation coefficient $(\mathrm{R})$. The $\mathrm{R}^{2}$ value of 0.9841 demonstrates the high degree of significance of the model and indicates that the independent variables explained $98 \%$ of the variability in enzyme activity, with only $2 \%$ not explained by the model. The high $R$ value $(0.9951)$ demonstrates strong agreement between the experimental and predicted values regarding CGTase production.

The response surface, 3D graph and contour plot representation of the regression equation demonstrate the interaction of the variables at their optimal levels for maximal response (Figure 1).

The rounded response surfaces propose optimal variables. The response surface for CGTase production represents different combinations of two variables while keeping the other variable at the zero level. The three variables $\mathrm{X}_{1}, \mathrm{X}_{2}$ and $\mathrm{X}_{3}$ had a significant effect on CGTase production at a $90 \%$ confidence level. An algorithm was used in the Maple 15 program to calculate the stationary point for the production of CGTase. The optimal concentration of sorghum, initial $\mathrm{pH}$ and temperature CGTase production from Bacillus circulans were $0.16 \%$ (Figures $1 \mathrm{~d}$ and 1e), 8.06 (Figures $1 \mathrm{~d}-1 \mathrm{f}$ ) and $34.78^{\circ} \mathrm{C}$, respectively (Figures 1e-1f). Predicted maximal enzymatic activity was $212.2 \mathrm{U} \cdot \mathrm{mL}^{-1}$, which is very close to the $211.40 \mathrm{U} \cdot \mathrm{mL}^{-1}$ obtained experimentally. Thus, the experimental design proved effective for the optimization of substrate concentration and experimental conditions for maximal CGTase production $[17,18]$.

Sorghum, initial $\mathrm{pH}$ and temperature were the relevant variables controlling CGTase production (Figures 1a-1c) and their strong interaction for CGTase production was expected. As different CGTase

\begin{tabular}{|c|c|c|c|c|c|c|c|}
\hline \multirow[t]{2}{*}{ Experiments } & \multicolumn{3}{|c|}{ Coded variables } & \multicolumn{3}{|c|}{ Real variables } & \multirow[b]{2}{*}{$\mathrm{EA}\left(\mathrm{U} \cdot \mathrm{mL}^{-1}\right)$} \\
\hline & $\mathrm{X}_{1}$ & $X_{2}$ & $x_{3}$ & $X_{1}$ & $X_{2}$ & $X_{3}$ & \\
\hline 1 & -1 & -1 & -1 & 0.152 & 7 & 34 & 135.63 \\
\hline 2 & -1 & -1 & 1 & 0.152 & 7 & 36 & 70.58 \\
\hline 3 & -1 & 1 & -1 & 0.152 & 9 & 34 & 115.21 \\
\hline 4 & -1 & 1 & 1 & 0.152 & 9 & 36 & 76.46 \\
\hline 5 & 1 & -1 & -1 & 0.172 & 7 & 34 & 157.77 \\
\hline 6 & 1 & -1 & 1 & 0.172 & 7 & 36 & 90.99 \\
\hline 7 & 1 & 1 & -1 & 0.172 & 9 & 34 & 118.33 \\
\hline 8 & 1 & 1 & 1 & 0.172 & 9 & 36 & 94.11 \\
\hline 9 & -1.68 & 0 & 0 & 0.145 & 8 & 35 & 130.44 \\
\hline 10 & 1.68 & 0 & 0 & 0.178 & 8 & 35 & 140.13 \\
\hline 11 & 0 & -1.68 & 0 & 0.162 & 6.32 & 35 & 85.11 \\
\hline 12 & 0 & 1.68 & 0 & 0.162 & 9.68 & 35 & 45.32 \\
\hline 13 & 0 & 0 & -1.68 & 0.162 & 8 & 33.32 & 194.45 \\
\hline 14 & 0 & 0 & 1.68 & 0.162 & 8 & 36.68 & 114.87 \\
\hline 15 & 0 & 0 & 0 & 0.162 & 8 & 35 & 216.94 \\
\hline 16 & 0 & 0 & 0 & 0.162 & 8 & 35 & 201.71 \\
\hline 17 & 0 & 0 & 0 & 0.162 & 8 & 35 & 205.87 \\
\hline 18 & 0 & 0 & 0 & 0.162 & 8 & 35 & 208.98 \\
\hline 19 & 0 & 0 & 0 & 0.162 & 8 & 35 & 211.40 \\
\hline
\end{tabular}

$\mathrm{EA}=$ enzyme activity; $\mathrm{X}_{1}=$ sorghum grain $(\%) ; \mathrm{X}_{2}=\mathrm{pH} ; \mathrm{X}_{3}=$ Temperature $\left({ }^{\circ} \mathrm{C}\right)$

Table 3: Central composite rotational design for optimization of carbon source, $\mathrm{pH}$ and temperature for production of CGTase by Bacillus circulans and respective enzyme activity. 
Citation: Bernardi NZ, Blanco KC, Monti R, Contiero J (2015) Optimization of Cyclodextrin Glycosyltransferase Production from Sorghum. J Food Ind Microbiol 1: 102. doi:10.4172/2572-4134.1000102

Page 4 of 5

\begin{tabular}{|c|c|c|c|c|}
\hline Factor & $\square$ & Standard error & Computed $t$-value & p-value \\
\hline Intercept & & & 209.1972 & 3.145447 \\
\hline$X_{1}^{d}$ & 0.092503 & 0.030230 & 5.8333 & 1.906315 \\
\hline $\mathrm{X}_{2}^{\mathrm{e}}$ & -0.136800 & 0.030230 & -8.6267 & 1.906315 \\
\hline $\mathrm{X}_{3}{ }^{f}$ & -0.381770 & 0.030230 & -24.0745 & 1.906315 \\
\hline $\mathrm{X}_{1}{ }^{2}$ & -0.033085 & 0.030230 & -2.7248 & 2.489621 \\
\hline$x_{2}^{2}$ & 0.019431 & 0.030230 & 1.6002 & 2.489621 \\
\hline $\mathrm{X}_{3}^{2}$ & 0.104507 & 0.030230 & 8.6067 & 2.489621 \\
\hline $\mathrm{X}_{1} \mathrm{X}_{2}$ & -0.440251 & 0.030815 & -27.2299 & 1.905937 \\
\hline$X_{1} X_{3}$ & -0.840758 & 0.030815 & -52.0016 & 1.905937 \\
\hline $\mathrm{X}_{2} \mathrm{X}_{3}$ & -0.329493 & 0.030815 & -20.3794 & 1.905937 \\
\hline
\end{tabular}

Table 4: Coefficients estimated by linear regression $\left(R^{2}=0.968 ;\right.$ adj. $\left.R^{2}=0.937\right)$.
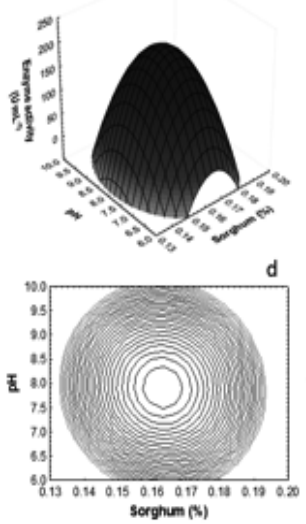
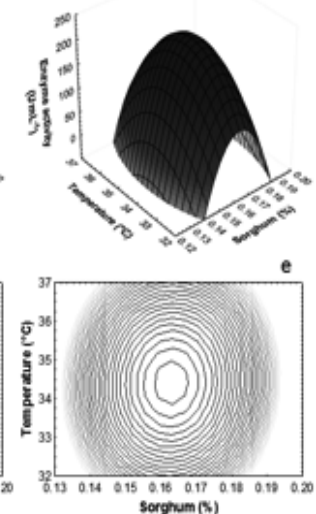
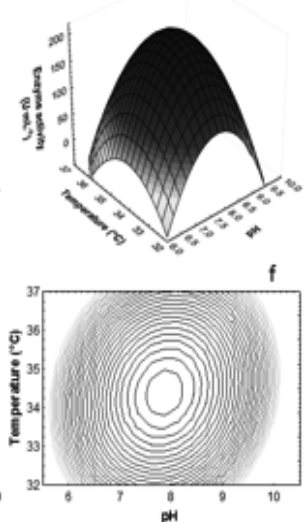

Figure 1: Response surface plot of enzyme activity: (a) sorghum starch and initial pH; (b) sorghum starch and temperature; (c) initial $\mathrm{pH}$ and temperature; Contour plot of enzyme activity: (d) sorghum starch and initial $\mathrm{pH}$; (e) sorghum starch and temperature; (f) initial $\mathrm{pH}$ and temperature.

bacteria require different carbon concentrations for growth, sorghum at higher and lower concentrations may inhibit CGTase production from Bacillus circulans due to catabolite repression or a lack of cell nutrients.

Sorghum starch is an inexpensive alternative to soluble starch. Starting materials account for 60 to $80 \%$ of the cost of enzyme production by fermentation [19]. The substitution of a soluble starch with $0.75 \%$ cassava starch achieves the highest CGTase yield at $72 \mathrm{~h}$ [20]. Alves-Prado et. al. found that, when associated with wheat, cassava can replace soluble starch as the carbon source in CGTase production, achieving 80.50 U.mL $\mathrm{mL}^{-1}$ of enzyme activity with E16 do Bacillus sp. The effect of the carbon source on CGTase production was positive in the present study, as sorghum is rich in starch and contains other elements, such as protein [8]. Previous studies have also investigated CGTase production by Bacillus circulans varying $\mathrm{pH}$ to increase CGTase production [21]. The use of $\mathrm{Na}_{2} \mathrm{CO}_{3}$ is reported to control $\mathrm{pH}$ for microorganism growth, as CGTase production was enhanced with the increase in $\mathrm{Na}_{2} \mathrm{CO}_{3}$ concentration to reach $\mathrm{pH} 8$ [22]. The positive effect of $\mathrm{pH}$ and temperature on CGTase production from Bacillus circulans has also been described by Rosso et al. who report optimal conditions of initial $\mathrm{pH} 8.3$ and $37^{\circ} \mathrm{C}$ [23].

The greatest enzyme activity for CGTase production was 216.94 U.mL ${ }^{-1}$ under optimized conditions obtained after 48 hours of culture with $0.16 \%$ sorghum, $0.5 \%$ triptone, $0.5 \%$ yeast extract, $1 \%$ sodium carbonate, $0.1 \% \mathrm{~K}_{2} \mathrm{HPO}_{4}$ and $0.02 \% \mathrm{MgSO} 4 \bullet 7 \mathrm{H}_{2} \mathrm{O}$ at an initial $\mathrm{pH}$ of 8 and temperature of $35^{\circ} \mathrm{C}$. Thus, the use of sorghum for fermentation by Bacillus circulans is viable and produces a considerable amount of CGTase. This study focused on high production in a rotational shaker. Further studies using sorghum as the carbon source with a scale increase in the fermentation process are needed to reduce the costs of CGTase production.

\section{Acknowledgment}

The authors would like to thank to the Brazilian National Council for Scientific and Technological Development (CNPq) for fellowships and financial support.

\section{References}

1. Connors KA (1997) The Stability of Cyclodextrin Complexes in Solution. Chem Rev 97: 1325-1358.

2. Leclercq L, Bricout H, Tilloy S, Monflier E (2007) Biphasic aqueous organometallic catalysis promoted by cyclodextrins: Can surface tension measurements explain the efficiency of chemically modified cyclodextrins? J Colloid Interf Sci 307: 481-487.

3. Szejtli J (1998) Introduction and General Overview of Cyclodextrin Chemistry Chem. Rev 98: 1743-1754.

4. Volkova DA, Lopatin SA, Varlamov VP (2000) One-step affinity purification of cyclodextrin glucanotransferase from Bacillus sp. Biocatalysis-2000: Fundamentals and Applications 41: 67-69.

5. Gunaratne A, Corke H (2007) Influence of unmodified and modified cycloheptaamylose ( $\beta$-cyclodextrin) on transition parameters of amylose-lipid complex and functional properties of starch. Carbohyd. Polym 68: 226-234.

6. Goh KM, Mahadi NM, Hassan O, Md Illias R (2009) A predominant $\beta$-CGTase $\mathrm{G} 1$ engineered to elucidate the relationship between protein structure and product specificity. J Mol Catal B-Enzym 57: 270-277.

7. Saier MH (1991) A multiplicity of potential carbon catabolite repression 
Citation: Bernardi NZ, Blanco KC, Monti R, Contiero J (2015) Optimization of Cyclodextrin Glycosyltransferase Production from Sorghum. J Food Ind Microbiol 1: 102. doi:10.4172/2572-4134.1000102

Page 5 of 5

mechanisms in prokaryotic and eukaryotic microorganisms. New Biol 3: 1137-1147.

8. Pedersen WL, Chakrabarty K, Klucas RV, Vidaver AK (1978) Nitrogen fixation (acetylene reduction) associated with roots of winter wheat and sorghum in Nebraska. Appl. Environ. Microb 35: 129-135.

9. Shen F, Hu J, Zhong Y, Liu MLY, Saddler JN, et al. (2012) Ethanol production from steam-pretreated sweet sorghum bagasse with high substrate consistency enzymatic hydrolysis. Biomass Bioenerg 41: 157-164.

10. Yadav AK, Bipinraj NK, Chaudhari AB, Kothari RM (2011) Production of L (+ lactic acid from sweet sorghum, date palm, and golden syrup as alternative carbon sources. Storch/Stärke 63: 632-636.

11. Nakamura N, Horikoshi K (1976) Characterization and Some Cultural Conditions of a Cyclodextrin Glycosyltransferase-producing Alkalophilic Bacillus sp. Agr Biol Chem 40: 753-757.

12. Makela MJ, Korpela TK, Puisto J, Laakso SV (1988) Nonchromatographic cyclodextrin assays: evaluation of sensitivity, specificity, and conversion mixture applications. J. Agr. Food Chem 36: 83-88.

13. Walker RD, Lichtenwalner RE (1977) Effect of Reconstitution on Protein Solubility and Digestibility of Waxy Sorghum. J. Anim. Sci. 44: 843-849

14. EA (2007) Enzymes in Industry: Production and Applications. Weinheim: Wiley$\mathrm{VCH}$.

15. Blanco KC, De Lima CJB, De Oliveira PAPLV, Pião ACSP, Contiero J (2009) Cyclodextrin Glycosyltransferase Production by the Bacillus sp., Subgroup alcalophilus using a Central Composite Design. Res J of Microb 4: 450-459.
16. Kulpreecha S, Boonruangthavorn A, Meksiriporn B, Thongchul N (2009) Inexpensive fed-batch cultivation for high poly (3-hydroxybutyrate) production by a new isolate of Bacillus megaterium. J Biosci Bioeng 107: 240-245.

17. Mahat MK, Illias RM, Rahman RA, Rashid NAA, Mahmood NAN, et al. (2004) Production of cyclodextrin glucanotransferase (CGTase) from alkalophilic Bacillus sp. TS1-1: Media optimization using experimental design. Enzyme Microb Tech 35: 467-473.

18. Zain WSWM, Illias RM, Salleh MM, Hassan O, Rahman RA et al. (2007) Production of cyclodextrin glucanotransferase from alkalophilic Bacillus sp. TS1-1Optimization of carbon and nitrogen concentration in the feed medium using central composite design. Biochem. Eng J 33: 26-33.

19. Uenojo M, Pastore M (2007) Pectinases: Aplicações industriais e perspectivas. Quim Nova 30: 388-394.

20. Blanco KC, De Lima CJB, Monti R, Martins J, Bernardi NS, et al. (2012) Bacillus lehensis - An alkali-tolerant bacterium isolated from cassava starch wastewater: Optimization of parameters for cyclodextrin glycosyltransferase production. Ann. of Microbiology 62: 329-337.

21. Szerman N, Schroh I, Rossi AL, Rosso AM, Krymkiewicz N, et al. (2007) Cyclodextrin production by cyclodextrin glycosyltransferase from Bacillus circulans DF 9R, Bioresource Technol 98: 2886-2891.

22. Freitas TLD, Monti R, Contiero J (2004) Production of CGTase by a Bacillus alkalophilic CGII strain isolated from wastewater of a manioc flour industry. Braz. J Microb 35: 255-260.

23. Rosso AM, Ferrarotti SA, Krymkiewicz N, Nudel C (2002) Glucanotransferase production from Bacillus circulans DF 9R, Microb Cell Fact 9: 1-9. 